\title{
Pendekatan Tri Hita Karana Dalam Meningkatkan Motivasi Berwirausaha Mahasiswa
}

\author{
Ni Kadek Yuliandari ${ }^{(1)}$ \\ Ni Nyoman Sunariani ${ }^{(2)}$ \\ Universitas 17 Agustus $1945^{(1)}$ \\ Universitas Pendidikan Nasional ${ }^{(2)}$ \\ adeqyuliandari@gmail.com ${ }^{(1)}$ \\ nyomansunariani@undiknas.ac.id ${ }^{(2)}$
}

\begin{abstract}
This research is used to find out more about the philosophy of Tri Hita Karana in improved students entrepreneurship motivation in STIE Satya Dharma Singaraja, by used lecturer and students as informants. This research is qualitative descriptive with approach case study. The results showed that the understanding of the philosophy of THK able to encourage the entrepreneurial spirit by promoting fairness as a reflection of aspects parahyangan, implement and uphold the work ethic of Hindus as a reflection of aspects pawongan, and always uphold the attitude of protecting and maintaining the environment as a reflection of aspects palemahan. With the foundation of the philosophy of THK, believed to be able to create an atmosphere that is harmonious and balanced in business.
\end{abstract}

\section{Keywords: entrepreneurship motivation; philosophy of tri hita karana}

\begin{abstract}
ABSTRAK
Penelitian ini digunakan untuk mengetahui lebih lanjut tentang filosofi Tri Hita Karana dalam meningkatkan motivasi kewirausahaan siswa di STIE Satya Dharma Singaraja, dengan menggunakan dosen dan mahasiswa sebagai informan. Penelitian ini adalah deskriptif kualitatif dengan pendekatan studi kasus. Hasil penelitian menunjukkan bahwa pemahaman filosofi THK mampu mendorong semangat kewirausahaan dengan mengedepankan keadilan sebagai cerminan dari aspek parahyangan, menerapkan dan menjunjung tinggi etos kerja umat Hindu sebagai refleksi dari aspek pawongan, dan selalu menjunjung tinggi sikap melindungi dan menjaga lingkungan sebagai cerminan dari aspek palemahan. Dengan dasar filosofi THK, diyakini mampu menciptakan suasana yang harmonis dan seimbang dalam bisnis.
\end{abstract}

\section{Kata kunci: motivasi kewirausahaan; filsafat tri hita karana}




\section{PENDAHULUAN}

Pada dasarnya, kewirausahaan merupakan faktor penentu bagi kemajuan suatu Negara. Salah satu tolok ukur untuk menentukan kemajuan suatu negara adalah ditentukan oleh pertumbuhan ekonomi dan pertumbuhan ekonomi dapat dicapai jika negara memiliki banyak wirausaha. Menurut pandangan dari McClelland dalam (Sutrisno, 2009) bahwa suatu negara bisa menjadi makmur bila ada entrepreneur sedikitnya $2 \%$ dari total jumlah penduduk. Data terkini dari Global Entrepreneurship Monitor (GEM) menunjukkan bahwa Indonesia hanya memiliki sekitar $1,65 \%$ pelaku wirausaha dari total jumlah penduduk 250 juta jiwa (kompas.com, 2016).

Generasi muda saat ini memang kurang tertarik dengan dunia wirausaha, mereka memiliki alasan yang beragam seperti dunia wirausaha penuh tantangan, resiko, dan rentan kerugian. Disamping hal tersebut, pemicu utamanya yakni dalam pembelajaran didalam kelas mahasiswa kurang mendapat bekal yang memadai ketika ingin menjadi seorang wirausaha, pembelajaran di dalam kelas dirasa kurang menyentuh prinsip-prinsip dasar yang membangun jiwa kewirausahaan, karena selama ini kurikulum yang berlaku, metode pembelajaran dan pengajaran tidak didesain untuk mengarah pada implikasi kewirausahaan, namun hanya sebatas pada pengertian dan pemahaman saja.

STIE Satya Dharma Singaraja merupakan salah satu Universitas swasta di Kabupaten Buleleng. Dengan mengusung Visi sebagai "Sekolah Tinggi yang berkualitas, berprestasi dan berjiwa kewirausahaan dengan berlandaskan spiritual". Dengan demikian kampus diharapkan mampu mendidik serta mencetak lulusannya agar memiliki semangat tinggi akan kewirausahaan yang berlandaskan atas nilai-nilai spiritual. Wujud dari strategi pembelajaran kreatif wirausaha salah satunya adalah dengan memasukkan mata kuliah kewirausahaan yang diwujudkan dengan implementasi pembuatan produk sekaligus memasarkan produk hasil dari kreativitas mahasiswa. Salah satu bentuk dukungan lembaga terhadap kegiatan ini adalah menyediakan wadah saat acara Dies Natalis yaitu pada acara pameran kewirausahaan.

Nilai-nilai budaya atau kearifan lokal yang melekat di dalam jati diri masyarakat Indonesia sangat beragam. Nilai-nilai kearifan lokal yang berkembang di suatu daerah sangat diyakini kebenarannya oleh masyarakat di daerah tersebut dan dirasa mampu menyentuh tatanan moral masyarakat dalam menjalankan segala bentuk aktivitas terutama dalam hal aktivitas bisnis. Di Bali khususnya, untuk menciptakan keselarasan antar elemen yang terdapat di bumi, elemen tersebut adalah manusia dan alam. Ajaran Tri Hita Karana diyakini dapat menyeimbangkan keseluruhan elemen tersebut. Saat ini ajaran THK telah berkembang dan 
diakui secara universal, serta digunakan hampir disegala aspek kehidupan manusia, terutama dapat diaplikasikan dalam aspek bisnis.

\section{Motivasi Berwirausaha}

Motivasi merupakan salah satu penggerak jiwa dan hati seseorang untuk melakukan atau mencapai suatu tujuan tertentu. Motivasi juga dapat dikatakan sebagai rencana atau keinginan untuk menuju kesuksesan dan menghindari kegagalan hidup. Dengan kata lain motivasi merupakan sebuah proses untuk tercapainya suatu tujuan. Seseorang yang memiliki motivasi berarti telah memiliki kekuatan untuk memperoleh kesuksesan dalam kehidupannya (Sumarwan, 2002).

Motivasi seseorang berasal dari intern dan ekstern. Herpen et al, (2002) dalam hasil penelitiannya menyatakan bahwa motivasi seseorang berupa intrinsik dan ekstrinsik. Faktor intrinsik maksudnya adalah motivasi berasal dari dalam diri manusia yang merupakan dorongan nuraninya dalam bertindak, kemudian faktor ekstrinsik merupakan suatu dorongan dari luar individu yang dapat menciptakan tumbuhnya semangat dalam diri seseorang.

Seseorang yang memiliki motivasi berwirausaha yang tinggi, akan melakukan suatu tindakan dalam proses bisnisnya, seperti melakukan suatu inovasi untuk mencapai orientasi labanya (Yunal dan Indriyani, 2013). Dengan demikian, motivasi berwirausaha merupakan suatu tindakan yang mampu mendorong jiwa seseorang untuk melakukan suatu usaha yang mampu memberikan dampat yang positif dimasyarakat dengan pendidikan yang baik demi terciptanya iklim wirausaha yang berbudaya dan berkarakter.

\section{Budaya}

Perilaku dari seorang wirausaha selalu berkaitan dengan nilai-nilai budaya (kultur) dari masyarakat setempat yang diyakini menjadi suatu kebiasaan, norma, adat istiadat yang berlaku secara turun-menurun pada suatu daerah yang diyakini serta dijunjung tinggi nilai dan maknanya. Manfaat budaya menurut Bourdieu (1977) dalam Sunariani (2014) menyatakan bahwa budaya memiliki dimensi pengetahuan, cita rasa, kemampuan praktis dan membedakan hal yang baik dan buruk maka modal budaya akan sangat terikat dengan sejarah dan konstruksi sosial masyarakat di suatu wilayah. Mueller dan Thomas (2001), Kreiser et al., (2002) menyatakan bahwa atribut-atribut kultural dapat memiliki dampak kuat pada pembentukan dan tingkah laku kewirausahaan.

Mayoritas penduduk Bali yang beragama Hindu dengan elemen pemujaan alam dan para leluhur adalah hasil evolusi dan akulturasi dari beberapa budaya yang datang ke pulau Bali. 
Konsep THK merupakan konsep nilai kultur lokal yang telah tumbuh, berkembang dalam tradisi masyarakat Bali, dan bahkan saat ini telah menjadi landasan falsafah bisnis, filosofi pengembangan pariwisata, pengaturan tata ruang, dan rencana stratejik pembangunan daerah (Riana, 2011). Konsep ini mengandung makna bagaimana mencari keharmonisan dengan tidak semata-mata mencari materi, namun bagaimana tujuan hidup untuk mendapatkan kebahagian yang kekal.

Umat hindu memiliki keyakinan atas keseimbangan keharmonisan yang telah menjadi tuntunan masyarakat Bali untuk berperilaku yang melahirkan berbagai tindakan nyata yakni : (1) Keselarasan hubungan manusia dengan Hyang Widhi (Tuhan) yang disebut parahyangan; (2) keselarasan hubungan dengan sesamanya disebut pawongan; (3) keselarasan hubungan manusia dengan alam sekitar disebut dengan palemahan. Ketiga hubungan ini dalam ajaran umat hindu dikenal dengan istilah Tri Hita Karana (THK).

\section{Grand Theory atau Teori Utama dalam Penelitian}

Peran teori sangat penting untuk menjelaskan suatu fenomena suatu penelitian. Penelitian ini menggunakan teori kewirausahaan sebagai teori utama atau grand theory. Weber (1956) dalam Osman and Murat (2011) menyatakan bahwa "pointed that entrepreneurship behaviour might be linked to cultural values and suggested that values and beliefs are factors that encourage entrepreneurship". Makna yang terkandung dalam teori ini adalah menunjukkan perilaku kewirausahaan yang terkait dengan nilai serta aktivitas budaya dan menyarankan bahwa nilai-nilai dan keyakinan merupakan faktor yang mendorong kewirausahaan. Hal ini diperkuat dengan pernyataan dari Gorda (2006) dalam Windia dan Ratna (2007) yang menyatakan bahwa konsep Tri Hita Karana bila dibumikan secara disiplin spiritual (sadana) dan cinta-kasih dan pengabdian (bhakti yoga), maka diyakini akan mampu mewujudkan semangat wirausahawan yang etis menuju sukses yang sejati didalam mengelola bisnisnya.

\section{Kerangka Pemikiran}

Berdasarkan Visi dari STIE Satya Dharma Singaraja, maka secara eksplisit tersirat makna bahwa dalam mendidik mahasiswa yang berjiwa kewirausahaan yaitu dengan berlandaskan spiritual. Spiritual dalam konsep agam hindu yang dapat dijadikan falsafah dasar yaitu melalui pendekatan kultur lokal $T H K$. 


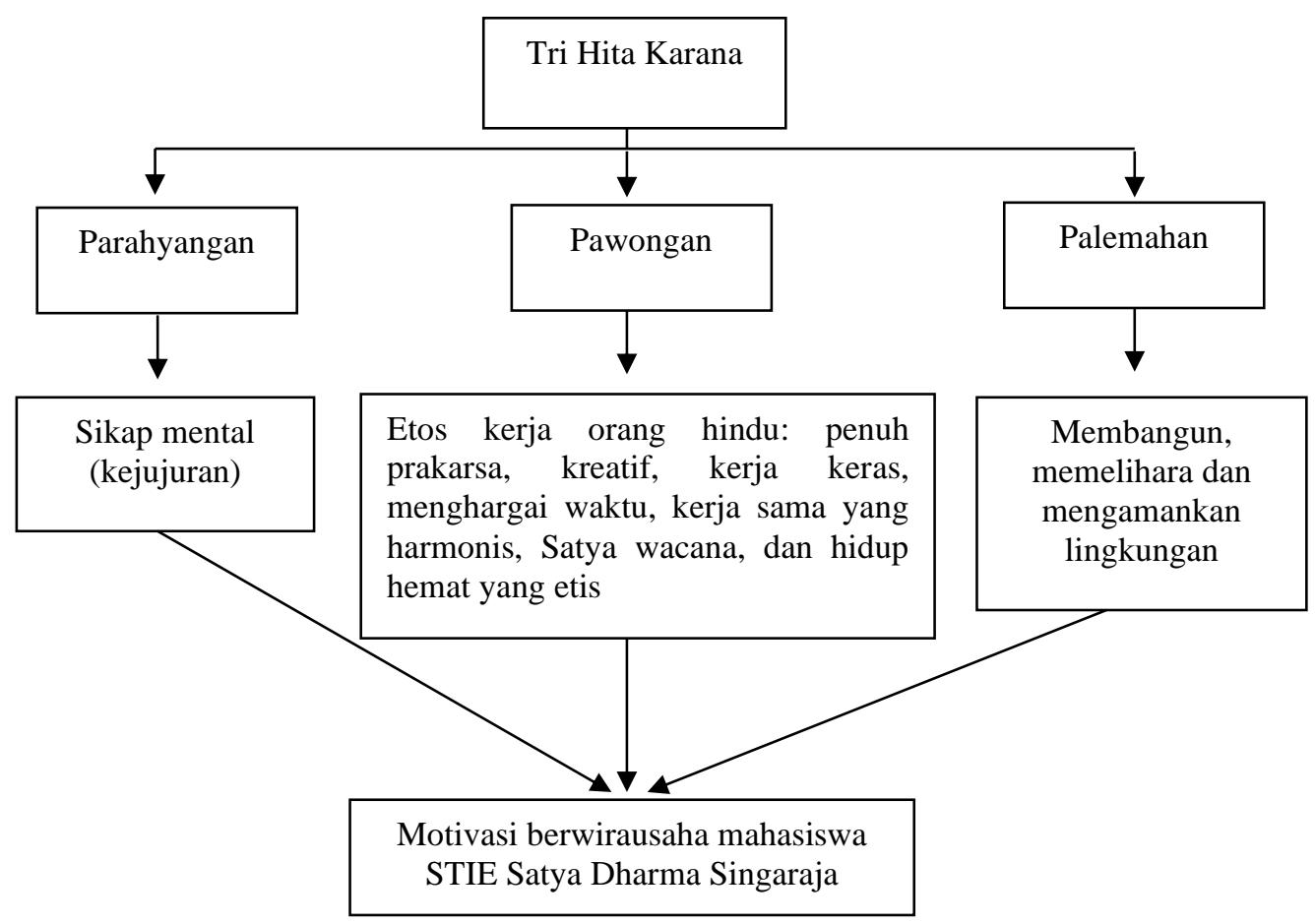

\section{METODE PENELITIAN}

Penelitian ini dilakukan di kampus STIE Satya Dharma Singaraja. Pemilihan lokasi ini dilandaskan pada kesesuaian visi misi yang dijalankan oleh kampus dengan makna yang ingin diperoleh dari hasil penelitian ini. Apabila lokasi penelitian diubah, tentu akan memperoleh hasil yang bias, sebab di kampus lain peneliti tidak menemukan visi misi yang sejalan dengan tujuan penelitian ini.

Penelitian ini merupakan penelitian yang besifat kualitatif. Jenis penelitian kualitatif yang digunakan yaitu penelitian kualitatif deskriptif dengan pendekatan studi kasus (case study).

Jenis data dalam penelitian ini adalah data kualitatif. Data kualitatif dianalisa dengan menganalisis jawaban hasil wawancara mendalam dan dokumentasi lapangan. Sedangkan sumber data terdiri atas sumber: 1) data primer berupa gambaran umum kampus STIE Satya Dharma Singaraja, hasil wawancara yang diperoleh melalui wawancara yang peneliti lakukan. Selain itu, peneliti juga melakukan observasi lapangan, dan dokumentasi terhadap lingkungan di kampus. Selanjutnya 2) data sekunder yang merupakan sumber data yang tidak memberikan informasi secara langsung kepada pengumpul data (Sugiyono, 2003:19). 
Informan penelitian ditunjuk dan ditentukan secara purposive. Informan penelitian terdiri atas dosen dan mahasiswa di lingkungan kampus STIE Satya Dharma Singaraja.

Teknik pengumpulan data pada penelitian ini yakni dengan cara melakukan wawancara mendalam serta observasi. Wawancara mendalam dilakukan pada informan penelitian untuk memperoleh hasil yang sesuai dengan tujuan penelitian ini.

Teknik pemeriksanaan keabsahan data dilakukan dengan proses triangulasi, dalam penelitian ini teknik triangulasi yang digunakan yaitu triangulasi dengan teori. Teknik ini dilakukan untuk melihat representasi data yang diperoleh dengan teori-teori yang ada dan berkembang saat ini.

Analisis data yang digunakan adalah analisis kualitatif yang bersifat mengutamakan makna. Makna yang diungkapkan dalam penelitian ini yakni terkait dengan persepsi seseorang terhadap suatu peristiwa yang diteliti. Dalam penelitian ini, peneliti ingin mencari kedalaman pemahaman tentang dampak yang dirasakan mahasiswa, serta bagaimana implementasinya di dunia nyata. Dalam implementasinya, apakah mahasiswa memperhatikan budaya sekitar yaitu THK. Makna yang ingin digali adalah terkait dengan motivasi berwirausaha dengan memperhatikan aspek budaya lokal yaitu THK. 


\section{PEMBAHASAN}

\section{Tri Hita Karana dalam Meningkatkan Motivasi Berwirausaha}

Generasi muda, khususnya mahasiswa mulai diarahkan untuk menjadi seorang pencipta lapangan pekerjaan, bukan lagi sebagai pencari kerja. Salah satu cara untuk menjadi pencipta lapangan perkerjaan yakni ditempuh dengan mengubah mindset dari pencari kerja menjadi pencipta lapangan kerja yaitu menjadi seorang wirausahawan.

Motivasi dalam berwirausaha penting dilakukan dalam dunia akademik sebagai upaya dalam menciptakan kreatifitas yang berdampak pada timbulnya hasrat mahasiswa untuk menjadi pencipta lapangan kerja, bukan pencari kerja. Hal ini dikarenakan, selama ini dogma yang tertanam dalam benak mahasiswa adalah ketika lulus bekerja diperusahaan besar, menjadi pegawai bank, menjadi PNS, bekerja di perusahaan BUMN, dan sejenisnya. Hal ini sebenarnya bukanlah hal yang salah, namun suatu bentuk kekeliruan yang menjadi pembenaran bagi sebagian orang ketika masih berpangku tangan menunggu panggilan wawancara. Alangkah lebih baiknya, sebagai generasi muda dengan pendidikan yang baik serta pemahaman dan wawasan yang luas, generasi muda ikut andil dalam pembangunan bangsa ini melalui gerakan menjadi wirausaha.

Adapun visi dari kampus STIE Satya Dharma Singaraja yakni "STIE Satya Dharma Singaraja sebagai Sekolah Tinggi yang berkualitas, berprestasi, dan berjiwa kewirausahaan berlandaskan spiritual". Berdasar dari visi ini, maka sudah jelas bahwa tujuan kampus yaitu menciptakan output atau lulusan yang memiliki jiwa wirausaha dengan berpegang teguh pada ajaran dharma atau kebaikan.

Budaya akan selalu dijunjung tinggi oleh masyarakat setempat, sejalan dengan hasil penelitian dari Osman dan Picak (2011) yang menyatakan bahwa "moreover, entrepreneurship concept varies from a country to another country, and an entrepreneur reflects the dominant values of his/her national culture". Hal ini memberi makna bahwa nilai-nilai kebudayaan tempat dimana seorang wirausaha tumbuh sangat mempengaruhi kepribadian dari wirausaha tersebut.

Konsep Tri Hita Karana terkait aspek parahyangan yang diinterpretasikan dengan sikap mental yang jujur seharusnya diimplementasikan dengan baik. Sebab, dalam tatanan ilmu dan teori, kejujuran tidak bisa diukur, kejujuran merupakan sikap mental dari manusia yang sesuai dengan hati nurani dan dipertanggungjawabkan dihadapan Tuhan Yang Maha Esa. Dalam 
ajaran agama, semua agama mengajarkan akan kebaikan, termasuk didalamnya menjunjung tinggi sikap jujur. Sehingga, dalam membentuk mental seorang wirausaha, sikap ini merupakan modal awal bagi kesuksesan bisnisnya.

Terkait dengan konsep THK yang ada di Bali, menjadi sangat penting dimaknai sebab konsep ini mengajarkan manusia untuk selalu ingat bahwa dalam melaksanakan aktivitas di dunia ini, harus senantiasa menjaga sikap demi terwujudnya suasana yang harmonis dan seimbang. Seperti yang dikemukakan oleh Ashrama (2005) bahwa manusia secara universal pada dasarnya akan selalu mencari harmoni, karena Tuhan memberikan jiwa kepada ciptaannya, termasuk dan khususnya kepada manusia. Hal ini lah sejatinya yang perlu dimaknai bahwa pada dasarnya manusia yang membutuhkan harmoni, dan harmoni itu sendiri manusia yang menciptakan. Sehingga, melalui konsep THK ini, diyakini mampu menjadi landasan dalam melakukan aktivitas terkait dengan aspek bisnis.

\section{Aspek Parahyangan dalam Wirausaha}

Dalam aspek bisnis, seorang wirausaha meyakini bahwa kesuksesan usahanya berkat tangan-tangan Tuhan yang tiada henti membantu manusia. Konsep ini terkait dengan teori dalam ekonomi makro yang dikemukakan oleh Adam Smith yang menyatakan bahwa seperti alam semesta yang berjalan serba teratur, sistem ekonomi pun akan mampu memulihkan dirinya sendiri (self adjustment), kerena ada kekuatan pengatur yang disebut sebagai tangantangan tak terlihat (invisible hands). Teori ini memang yang dimaksudkan adalah mekanisme pasar, namun apabila ditarik kedalam konsep parahyangan yang diyakini oleh umat hindu, artinya dibalik kelancaran usaha bisnis yang dijalani, melalui manusia yang dibekali akal (manah) Tuhan menunjukkan eksistensinya dalam membantu kelancaran aktivitas umat manusia, terutama kaitannya dalam aspek bisnis.

Dalam dunia bisnis menjadi penting memiliki sikap atau attitude yang baik karena attitude merupakan ceriminan pribadi seseorang. Namun, bukan berarti suatu kemustahilangan di era globalisasi ini menjumpai pebisnis yang jujur. Terbukti dari adanya konsep sociopreneurship yang kegiatannya membangkitkan usaha-usaha kecil, kepedulian semacam ini merupakan suatu bentuk sikap yang baik dan peduli terhadap kehidupan orang-orang sekitar. Konsep sociopreneurship ini bisa dipahami melalui konsep yang dicetuskan oleh M. Yunus yang merupakan peraih peraih Nobel Perdamaian 2006 dan pendiri bank kaum miskin 
(Grameen Bank) di Bangladesh yang mengajarkan manusia untuk memiliki rasa empati terhadap manusia lainnya, sehingga sinergisitas antara manusia dengan manusia dapat terwujud tidak hanya melalui konsep pawongan, akan tetapi melalui aspek parahyangan, yakni memaknai bahwa tidak cukup hanya dengan berbuat jujur, namun harus berbuat baik sebagai wujud bakti manusia sebagai mahluk ciptaan Tuhan.

Dengan memegang teguh konsep menjadi wirausaha yang jujur, maka niscaya keberlangsungan dari usaha akan mampu tercipta sesuai dengan apa yang diharapkan oleh wirausaha itu sendiri. Sebagai seorang pendidik, harus dipahami bahwa perguruan tinggi dianggap sebagai lembaga yang paling ideal dalam mengembangkan minat berwirausaha di kalangan mahasiswa. Salah satu model pembentukan minat mahasiswa yakni melalui pendidikan kewirausahaan dan pengembang softskill mahasiswa sebagai perpaduan untuk membentuk pengetahuan dan karakter wirausaha.

\section{Aspek Pawongan dalam Wirausaha}

Aspek pawongan atau hubungan harmonis antara manusia dengan manusia lainnya diinterpretasikan dengan konsep menerapkan etos kerja umat hindu yang tercermin melalui sikap penuh prakarsa, kreatif, kerja keras, menghargai waktu, kerjasama yang harmonis, satya wacana, dan hidup hemat yang etis. Etos kerja dapat pula diartikan sebagai semangat kerja yang menjadi ciri khas dan keyakinan seseorang atau suatu kelompok. Dengan demikian, menurut Gorda (1996) menyatakan bahwa etos kerja umat hindu ini ternyata sesuai dengan ciri-ciri etos kerja yang dibutuhkan dan menjadi syarat modernisasi yang dilakukan oleh suatu Negara.

Dalam aktivitas bisnis, demi menjaga sikap kerjasama yang harmonis antar sesama umat, dapat diterapkan konsep tat twam asi yang artinya aku adalah kamu, kamu adalah aku. Ajaran ini sebenarnya bersifat universal, dibuktikan dengan adanya sikap memanusiakan manusia, yang bermakna bahwa dalam kehidupan ini hendaknya manusia bersikap manusiawi dengan sesama. Sehingga, dengan berpegang teguh pada konsep ajaran ini, sebagai umat beragama tidak akan memperlakukan sesama umatnya dengan semena-mena atau tidak manusiawi.

Etos kerja umat hindu menjadi sikap atau penanaman etika yang paling esensial dalam diri seseorang. Sebab, label sebagai umat hindu sudah seharusnya tertanam sikap mental yang 
terangkum dalam etos kerja tersebut. Dengan berpegang teguh pada etos kerja tersebut, maka dalam melakukan suatu pekerjaan, ciri-ciri tersebut melekat dalam diri umat hindu pada khususnya. Sehingga, yang membedakan gerak atau cara kerja seseorang adalah melalui keyakinan akan dirinya tentang etos kerja yang diyakini kebenarannya.

Seorang wirausaha yang berpegang teguh pada aspek-aspek ini niscaya usaha yang ditekuninya akan tercipta kesinambungan dalam jangka waktu yang panjang. Dalam ajaran agama hindu ditegaskan melalui kitab atharvaveda, VIII.115.4 dalam (Gorda, 1996) yaitu "gunakanlah kemajuan dan keuntungan perusahaan demi kesejahteraan bersama". Mantram ini bermakna bahwa agama hindu sendiri menginginkan agar wirausahawan senantiasa memelihara hubungan kerjasama yang harmonis dengan sesama manusia dalam hal ini karyawan, pelanggan, dan pemasok. Agama lainpun pasti mengajarkan hal yang sama, sebab menjaga hubungan baik dengan sesama demi terciptanya suasana damai, selaras dan harmoni merupakan harapan dan cita-cita universal bagi semua umat manusia.

Kesadaran tinggi akan karyawan merupakan asset perusahaan yang paling utama menjadikan seorang wirausahawan berprilaku etis dalam mengembangkan serta memelihara karyawannya. Sehingga, atas dasar itulah pemberian gaji yang layak dan tunjangan berupa jaminan sosial menjadi suatu kewajiban bagi seorang wirausahawan. Sikap ini merupakan cerminan sikap etis yang professional bagi kalangan wirausahawan. Ditinjau melalui keyakinan agama hindu tentang empat tujuan hidup atau dikenal dengan istilah catur purusha artha yang mencakup dharma (kebaikan atau kebenaran absolut), artha (harta), kama (hawa nafsu), dan moksa (tujuan tertinggi umat hindu). Kaitannya dengan sikap etis wirausahawan adalah seorang wirausahawan dalam meraih harta (artha) dalam memenuhi hawa nafsu atau keingan (kama) haruslah melalui jalan yang benar (dharma). Sehingga, kebudayaan apapun yang memiliki filosofi yang positif harus senantiasa diingat oleh seseorang, khususnya wirausahawan yang menjalani aktivitas bisnis di Bali.

Menjadi seorang wirausaha di Bali pada khususnya harus memperhatikan kearifan lokal atau local wisdom yang ada di Bali. Salah satunya yaitu kebudayaan menyama braya dengan mengedepankan aktivitas ngayah didalamnya. Menjadi wirausaha di Bali diharuskan memberikan toleransi akan kebuyaan ini demi menjaga keajegan budaya Bali. Aktivitas ngayah ini biasanya dilakukan ketika diselenggarakannya upacara piodalan di tempat suci umat hindu (Pura), upacara adat yaitu ngaben, upacara pernikahan, upacara tiga bulanan anak atau 
nyambutin dan upacara lain yang membutuhkan karma banjar untuk melakukan aktivitas ngayah.

Filosofi segilik, seguluk, salunglung sebayantaka, paras paros sarpanaya juga menjadi hal yang patut diperhatikan dan disadari oleh para wirausaha yang ada di Bali. Arti dari filosofi segilik, seguluk, salunglung sebayantaka, paras paros sarpanaya adalah (suka duka, tolong menolong berat sama dijinjing berat sama dipikul) juga sebagai wujud menjaga persatuan dan kesatuan, mewujudkan sikap gotong royong, serta suka dan duka pikul bersama-sama (Gunadha 2012: 23). Dalam melakukan aktivitas sehari-hari, khususnya dalam dunia bisnis, sikap ini tercermin melalui sikap saling membutuhkan satu sama lain, yang mengakibatkan terjadinya interaksi yang positif dan saling menguntungkan satu sama lain. Sehingga, demi menjaga hubungan yang harmonis antara manusia denga manusia lainnya, konsep ini patut diimplementasikan dengan baik bagi para wirausahawan.

Terciptanya motivasi dalam berwirausaha menjadikan manusia lebih kreatif dan mau berbenah diri. Terlebih untuk kalangan mahaasiswa yang selama ini tertanam konsep untuk mencari kerja diperusahaan, menjadi PNS, dan profesi lainnya. Dengan semangat wirausahawan yang tinggi serta pemahaman yang baik akan kondisi bisnis saat ini diyakini wirausahawan mampu bersaing dan melakukan aktivitas bisnis sesuai dengan aturan, norma dan kebudayaan yang dijunjung tinggi nilainya oleh masyarakat setempat. Sikap menghargai satu sama lainnya, terutama dalam aspek hubungan yang harmonis antar sesama dalam aktivitas bisnis juga sudah seharusnya dilestarikan sebagai suatu kebiasaan yang mampu membangun sinergi positif dalam aspek bisnis.

\section{Aspek Palemahan dalam Wirausaha}

Konsep dalam kebudayaan lokal yang terakhir yakni aspek palemahan yang meyakini untuk mewujudkan hubungan yang harmonis antara manusia dengan lingkungan alam. Sinergi hubungan harmonis yang antara manusia dengan lingkungan diyakini sebagai sumber kebahagiaan dan kesejahteraan bagi manusia. Manusia tidak bisa melepaskan diri dari berbagai pengaruh alam sekitarnya, dan sebaliknya manusia juga dapat mempengaruhi alam sekitarnya. Hal ini berarti, adanya hubungan timbal balik antara keduanya, sehingga hubungan tersebut mampu menciptakan hubungan yang fungsional. Situasi yang muncul dari hubungan timbal balik itulah dimaksud dengan keselarasan hubungan antara manusia dengan alam sekitarnya. 
Dalam konsep bisnis, hubungan timbal balik ini diwujudkan dalam bentuk kepedulian terhadap kelestarian lingkungan. Selanjtnya, hal inilah yang mendasari perusahaan menyisihkan sedikit laba perusahaannya untuk program tanggungjawab sosial perusahaan atau Corporate Social Responsibility (CSR). Melalui program CSR ini perusahaan langsung dapat ikut berkontribusi demi kelestarian lingkungan sekitarnya. Aspek palemahan menjadi sangat penting untuk diperhatikan mengingat dalam kehidupan di dunia ini terjadi hubungan fungsional antara manusia dengan alam atau lingkungan.

filosofi THK ini merupakan suatu yang harus disinergikan. Apabila dimaknai, pertama menyangkut pada kekhawatiran akan limbah, sehingga perusahaan wajib untuk membuat saluran limbah agar tidak tercemar. Hal ini perlu dilakukan mengingat adanya UU No 32 Tahun 2009 yang mengatur tentang AMDAL, yang merupakan suatu kajian mengenai dampak besar dan penting suatu usaha dan/atau kegiatan yang direncanakan pada lingkungan hidup. AMDAL merupakan salah satu instrument pencegahan pencemaran dan/atau kerusakan lingkungan hidup.

Kedua, untuk program CSR yang diatur dalam UU No. 40 Tahun 2007 mengenai tanggungjawab sosial dan lingkungan perseroan terbatas serta untuk LPD di Bali melalui PERGUB No. 11 Tahun 2013 BAB VIII Ps. 75-76 tentang penyetoran dan penggunaan keuntungan bersih LPD, CSR merupakan suatu kewajiban dan keharusan bagi perusahaan sebagai bentuk kepedulian terhadap lingkungan.

Sinergi dari konsep filosofi Tri Hita Karana dalam dunia bisnis menjadi suatu keharusan. Hal ini disebabkan karena konsep ini memiliki nilai-nilai luhur yang mendunia dan bersifat universal. Maksudnya adalah nilai-nilai dalam filosofi THK sebenarnya diajarkan pula pada berbagai belahan dunia namun dengan nama yang berbeda. Konsep THK menjadi pegangan dalam aspek bisnis karena pada dasarnya fluktuasi dalam bisnis membutuhkan sinergi antara ketiga aspek yang terdapat dalam ajaran THK yakni hubungan yang harmonis antara manusia dengan Tuhan, kemudian hubungan antara manusia dengan manusia lainnya, dan terakhir hubungan manusia dengan lingkungan sekitar atau alam. 


\section{PENUTUP}

Berdasarkan hasil interpretasi dari pembahasan yang telah dikemukakan, maka simpulan dari penelitian ini adalah sebagai berikut. Motivasi berwirausaha mahasiswa STIE Satya Dharma Singaraja tercermin melalui pemahaman dari makna kearifan lokal yang diyakini orang Bali yakni Tri Hita Karana. Segala bentuk aktivitas yang dilakukan oleh mahasiswa STIE Satya Dharma Singaraja mengacu pada pemahaman masing-masing akan makna yang melekat dalam filosofi tersebut. Dengan pemahaman yang kuat tentang filosofi Tri Hita Karana mahasiswa STIE Satya Dharma Singaraja mampu menjadi pebisnis yang beretika dengan senantiasa mengedepankan sikap positif demi terciptanya hubungan yang harmonis. Peran dari filosofi Tri Hita Karana dalam meningkatkan motivasi berwirausaha mahasiswa tercermin melalui sikap mahasiswa STIE Satya Dharma Singaraja yang senantiasa menjaga sinergisitas aspek bisnisnya melalui tiga aspek yang terdapat dalam filosofi Tri Hita Karana, yakni aspek parahyangan melalui sikap yang menjaga integritas agar senantiasa menjunjung tinggi sikap jujur. Kemudian, aspek pawongan dengan mengimplementasikan etos kerja umat hindu dan sikap tat twam asi serta pemahaman filosofi segilik, seguluk, salunglung sebayantaka, paras paros sarpanaya demi menjaga sinergisitas antara manusia dengan manusia lainnya. Terakhir, aspek palemahan tercermin melalui sikap etis dalam menjaga dan melestarikan lingkungan, serta pemahaman kuat akan etika bisnis yakni CSR dan AMDAL.

Berdasarkan hasil penelitian tersebut maka peneliti dapat memberikan beberapa saran yang nantinya dapat digunakan untuk lebih memotivasi mahasiswa STIE Satya Dharma Singaraja dalam berwirausaha. Adapun saran yang dapat disampaikan oleh peneliti adalah sebagai berikut. Dari simpulan yang diperoleh mengenai pendekatan Tri Hita Karana dalam memotivasi wirausaha mahasiswa STIE Satya Dharma Singaraja, ternyata aspek parahyangan, pawongan, dan palemahan telah tercermin dalam pribadi mahasiswa, untuk pembelajaran mata kuliah kewirausahaan, kedepannya diharapkan untuk lebih ditekankan pemahaman Tri Hita Karana, serta pemahaman akan filosofi-filosofi lainnya yang diyakini mampu membangkitkan semangat wirausaha mahasiswa. Sebab, filosofi yang ada di Bali sebenarnya apabila dipahami memiliki makna yang universal. Untuk penelitian di masa yang akan datang agar lebih menyempurnakan lagi penelitian ini dengan menambahkan filosofi Tri Kaya Parisudha, melalui filosofi ini agar digali lebih dalam lagi dari aspek pemikiran, perkataan, dan perbuatan yang mampu menumbuhkan semangat kewirausahaan mahasiswa. 


\section{DAFTAR PUSTAKA}

Ashrama, B. (2005). Implementasi Konsep Tri Hita Karana pada beberapa Hotel di Bali, Thesis program MM-Unud, Denpasar.

Gunadha, I.B. (2012). Aneka Politik Hindu. Denpasar: Penerbit Widya Dharma, bekerja sama dengan Program Pascasarjana Universitas Hindu Indonesia.

Gorda, I.G.N. (2006). Manajemen Sumber Daya Manusia. Singaraja: Sekolah Tinggi Ilmu Ekonomi Satya Dharma.

Herpen, M., Praag, M., and Cools, K. (2002). The Effects of Performance Measurement and Compensation on Motivation and Emperical Study. Conference of The Performance Measurement Association in Boston.

Kreiser, P.D., Marino., and Weaver, K.M. (2002). Assessing the Psychometric Properties of Entrepreneurial Orientation Scale: A Multi - Country Analysis, Journal of Entrepreneurship Theory and Practise, 26: 71 - 103.

Muller, S. L., and Thomas, A.S. (2000). Culture and Entrepreneurial Potential: A Nine Country Study of Locus Control and Innovativeness, Journal of Business Venturing, 16 (1): 51 75.

Osman, E., and Piçak, M. (2011). Entrepreneurship, National Culture and Turkey, International Journal of Business and Social Science, 2 (16).

Riana, I.G. (2011). Dampak Penerapan Kultur Lokal Tri Hita Karana terhadap Orientasi Kewirausahaan dan Orientasi Pasar, Jurnal Teknik Industri, 13 (1): 37-44.

Sunariani, N.N. (2014). Kontribusi Pelaksanaan Ritual Terhadap Kesempatan Kerja Dan Kesejahteraan Masyarakat: Studi Kasus Mlaspas Dan Ngenteg Linggih Di Pura Pasek Preteka Desa Abiansemal, Kecamatan Abiansemal, Kabupaten Badung. Disertasi Universitas Udayana, Denpasar.

Sutrisno, E. (2009). Manajemen Sumber Daya Manusia edisi Pertama. Jakarta: Kencana Prenada Media Grup

Sumarwan, U. (2002). Perilaku Konsumen (Teori dan Penerapannya dalam Pemasaran). Bogor: Ghalia Indonesia

Windia, W., dan Ratna, K.D. (2007). Analisis Bisnis yang Berlandaskan Tri Hita Karana. Denpasar: Universitas Udayana. 
Yunal, V.O., dan Inriyani, R. (2013). Analisa Pengaruh Motivasi Berwirausaha Dan Inovasi Produk Terhadap Pertumbuhan Usaha Kerajinan Gerabah Di Lombok Barat, Jurnal Agora, 1 (1). 